\title{
An Ecofriendly Alternative for the Removal of Cd (II) and Cu (II) from Aqueous Medium
}

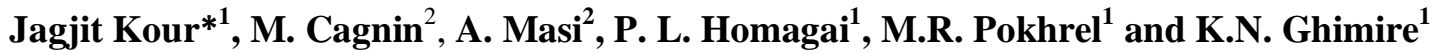 \\ ${ }^{1}$ Central Department of Chemistry, Tribhuvan University, Kirtipur, Kathmandu, Nepal. \\ ${ }^{2}$ Department of Agricultural Biotechnology, Padua University, Legnaro, Italy. \\ e-mail: jagjit_kour@hotmail.com
}

\begin{abstract}
Different types of agricultural waste materials have been explored for their efficiency in removing heavy metal ions from aqueous solution. A biomass of Desmostachya bipinnata (DB) was investigated as the potential bio-adsorbent for the removal of $C d(I I))$ and $C u(I I)$ from wastewater. The surface of DB was chemically grafted with ethylenediamine. It was characterized by elemental, FTIR and SEM analysis. The maximum adsorption capacity of MDB in the removal of $C d$ (II) and $C u$ (II) were $30.4 \mathrm{mg} / \mathrm{g}$ and 41.6 $\mathrm{mg} / \mathrm{g}$ at their optimum $\mathrm{pH} 6$ and 5, respectively. The experimental data followed the Langmuir isotherm and pseudo-second order kinetic model The research results indicated that D. bipinnata can be an alternative, efficient and ecofriendly material for the removal of $\mathrm{Cd}(\mathrm{II})$ and $\mathrm{Cu}$ (II) from wastewater.
\end{abstract}

Keywords: Desmostachya bipinnata, Biosorption, Heavy metals, Batch experiment, Pseudosecond order kinetic model, Ecofriendly.

\section{Introduction}

Water pollution caused by heavy metals is a matter of great environmental concern. The common toxic heavy metals found in industrial wastewater are $\mathrm{Pb}, \mathrm{Cd}, \mathrm{Cr}, \mathrm{Ni}, \mathrm{Mn}, \mathrm{Hg}, \mathrm{Cu}$ and $\mathrm{Zn}^{1,2}$. Appreciable concentration of these metal ions in water supplies exceeding the standard, constitutes a sever health hazard. Their harmful effects in aquatic environment include accumulation in living species and magnification throughout the food chain ${ }^{3}$. Cd (II) is one of the most toxic metal which is exposed to environment from welding, electroplating, pesticide fertilizer and Cd-Ni battery which can cause kidney damage, gastrointestinal disorder, bone marrow cancer and bronchitis ${ }^{4,5}$. Although $\mathrm{Cu}$ is an essential metal, extensive intake leads to sever mucosal irritation, hepatic and renal damage, hemolytic and heart failure and muscleache ${ }^{6}$.

Under such circumstances, these metal ions should be removed prior to their discharge into environment. The presently existing techniques for the removal of low concentration of heavy metals from wastewater include membrane separation, ion exchange and adsorption. Recently many researchers have given attention for the investigation of new adsorbent materials which are cost effective, efficient as well as eco-friendly. In this regard, agricultural waste, different types of algae, seaweeds, sunflower stalks, fruit peels, and tea waste are used. They are renewable, easily available in the local level with low $\operatorname{cost}^{7,8}$. The present study explores the possibility to introduce amine functional group into cellulose network contained in $\mathrm{DB}$, for the effective removal of heavy metals from aqueous solution.

\section{${ }^{*}$ Corresponding author}


J. Nepal Chem. Soc., vol. 30, 2012

\section{Experimental Methods}

\section{Sample preparation}

The plants of Desmostachya bipinnata were dried, cut and ground in to fine powder This sample is referred to as raw Desmostachya bipinnata (RDB) which was chemically modified with ethylenediamine after acid treatment for better adsorption of metal ions. Thus prepared biosorbent is known as modified Desmostachya bipinnata (MDB).

$1000 \mathrm{mg} / \mathrm{L}$ of standard stock solution of Cadmium (II)) and Copper (II) metal ions were prepared from analytical grade of Cadmium nitrate and Copper sulphate using milli-Q deionized water. All the working solutions of various concentrations $(25,50,100,200,400,600$ and $800 \mathrm{mg} / \mathrm{L})$ were prepared by diluting the standard stock solution with $0.1 \mathrm{M}$ nitric acid and $0.1 \mathrm{M}$ 2-[4-(hydroxymethyl )-1piperazinyl] ethanesulphonic acid (HEPES) was used as buffering agent in all working solutions 9 .

\section{Effect of $p H$}

The effect of $\mathrm{pH}$ onto $\mathrm{Cd}$ (II) and $\mathrm{Cu}$ (II) metal ions were analyzed over the $\mathrm{pH}$ range from one to seven. $50 \mathrm{mg} / \mathrm{L}$ of metal solution was taken in a beaker and $\mathrm{pH}$ was adjusted by adding dilute nitric acid and sodium hydroxide solution as required, with constant stirring. $20 \mathrm{ml}$ of Cd (II) metal solution at $\mathrm{pH}-1$ was taken in two separate conical flasks and $25 \mathrm{mg}$ of biosorbent (MDB) was added in only one conical flask covered the mouth with paraffin paper and shaken in a shaker at $23{ }^{\circ} \mathrm{C}$ for $24 \mathrm{~h}$ at $150 \mathrm{rpm}$. The next flask with $20 \mathrm{ml}$ of metal solution was taken as the reference. After $24 \mathrm{~h}$, it was filtered through cellulose free filter paper and $\mathrm{pH}$ was analyzed using $\mathrm{pH}$-meter and concentration of the metal ion was monitored using ICP-AES. The same process was repeated for all the respective metal ions at all $\mathrm{pH}$ from one to seven.

\section{Effect of Metal ions concentration}

Working solutions of 25, 50, 100, 200, 400, 600 and $800 \mathrm{mg} / \mathrm{L}$ were prepared by diluting the standard stock solution with $0.1 \mathrm{M}$ nitric acid and 0.1 M HEPES as the buffering agent. $20 \mathrm{ml}$ of metal solution of various concentrations were taken at their optimum $\mathrm{pH}$ (6 and 5 for $\mathrm{Cd}$ (II) and $\mathrm{Cu}$ (II), respectively) in conical flasks separately then $25 \mathrm{mg}$ of biosorbent (MDB) was added in each flask, covered the mouth with paraffin paper and shaken in a shaker at $23^{\circ} \mathrm{C}$ at $150 \mathrm{rpm}$ for $24 \mathrm{~h}$. Reference solution of each concentration was kept for analysis. After $24 \mathrm{~h}$ of shaking, the solutions were filtered and the residual metal ions concentrations were measured using ICP-AES. The results obtained were analyzed using Langmuir Isotherm for each metal ions. References of each metal ions were run to detect any metal precipitation. From the metal ion concentration measured before and after the adsorption $\left(\mathrm{C}_{\mathrm{i}} \mathrm{mg} / \mathrm{L}\right.$ and $\mathrm{C}_{\mathrm{e}}$ $\mathrm{mg} / \mathrm{L})$ and dry weight of adsorbent $(\mathrm{W}, \mathrm{gm})$, as well as volume of aqueous metal ions solution $(\mathrm{V}, \mathrm{ml})$, the amount of adsorption of metal ions $(\mathrm{q}, \mathrm{mg} / \mathrm{g}$ ) was calculated according to equation (1) .The adsorption percentage $(\mathrm{A} \%)$ defined as the ratio of the decrease in metal ion concentration in aqueous solution before and after the adsorption $\left(\mathrm{C}_{\mathrm{i}}-\mathrm{C}_{\mathrm{e}}\right)$ to its initial concentration $\left(\mathrm{C}_{\mathrm{i}}\right)$ was calculated according to equation (2)

$$
\begin{aligned}
q & =\frac{\mathrm{C}_{i}-\mathrm{C}_{\mathrm{e}}}{\mathrm{W}} \mathrm{X} \mathrm{V} \\
A \% & =\frac{C_{i}-C_{e}}{C_{i}} \times 100
\end{aligned}
$$




\section{Effect of contact time}

The effect of contact time of the metal ions onto MDB was analyzed as the function of time at an initial concentration of $50 \mathrm{mg} / \mathrm{L}$ solution. In this study $20 \mathrm{ml}$ of metal ions solution were taken in 14 different conical flasks and $25 \mathrm{mg}$ of biosorbent was added in each flask covered with paraffin paper and shaken at $23{ }^{\circ} \mathrm{C}$ at $150 \mathrm{rpm}$ for different interval of time ranging from 5 minutes to 360 minutes. After the completion of each shaking time the solution was filtered and corresponding concentrations were measured using ICP-AES (SPECTRO, Analytical Instruments, Kleve, German).

\section{Results and Discussion}

The amount of carbon and nitrogen was found to be $41.27 \%$ and $1.13 \%$ in raw Desmostachya bipinnata (DB). After chemical modification, percentage of nitrogen was found to be $5.49 \%$. Increase in nitrogen percentage shows the introduction of amino group in the biosorbent.



(1a)

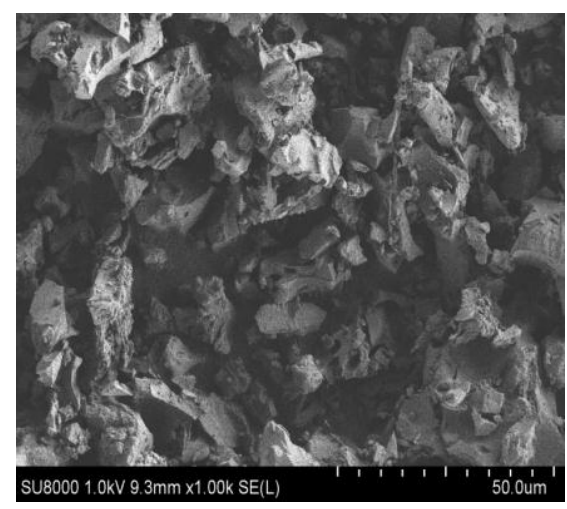

(1b)

Figure 1: Scanning electron microscope (SEM) photographs of (1a) RDB and (1b) MDB

Surface morphology of DB was studied with scanning electron microscope (SEM) before and after chemical modification. The morphological difference on the surfaces of RDB and MDB can be visualized in figure $1 \mathrm{a}$ and $1 \mathrm{~b}^{8}$.It is found that the surface of the MDB became much rough with porous structure than that of the RDB, after surface modification reaction. The introduction of the amino group on the surface of the biosorbent can therefore be expected to change the material's properties and thus affects the metal ion adsorption.

FTIR spectra have been a useful tool in identifying the presence of certain functional groups in a molecule ${ }^{10}$. To confirm the types of functional groups on the biosorbent before and after chemical modification, FTIR spectra of RDB and MDB were determined and are shown in figure 2. The characteristic peaks in the spectrum of RDB can be assigned as follows. $3409 \mathrm{~cm}^{-1}(\mathrm{OH}$ stretching $), 2926$ $\mathrm{cm}^{-1}$ (CH stretching in $\mathrm{CH}_{2}$ and $\mathrm{CH}_{3}$ groups), $1736 \mathrm{~cm}^{-1}$ (C=O stretching), 1426-1369 $\mathrm{cm}^{-1}$ (O-H bonding), $1169-1083 \mathrm{~cm}^{-1}$ (C-O stretching vibration of alcohol) ${ }^{11,12}$. After the chemical modification of biosorbent, the spectrum of MDB shows some significant changes in figure 2. The intense sharp peak at $3409 \mathrm{~cm}^{-1}$ in RDB has been shifted to $3393 \mathrm{~cm}^{-1}$ as a broad peak in MDB, which suggest the overlapping of hydroxyl groups with amine groups in MDB. Similarly peak at $1639-1588 \mathrm{~cm}^{-1}$ in RDB are overlapped as a broad peak in MDB, indicates the amine group introduction onto the surface of chemically modified biosorbent. Some of the peaks of RDB at $2926 \mathrm{~cm}^{-1}, 1124 \mathrm{~cm}^{-1}, 1169 \mathrm{~cm}^{-1}$, are significantly reduced in MDB, where as some peaks at $1736 \mathrm{~cm}^{-1}, 1466 \mathrm{~cm}^{-1}, 1245 \mathrm{~cm}^{-1}, 883 \mathrm{~cm}^{-1}$ are lost. 


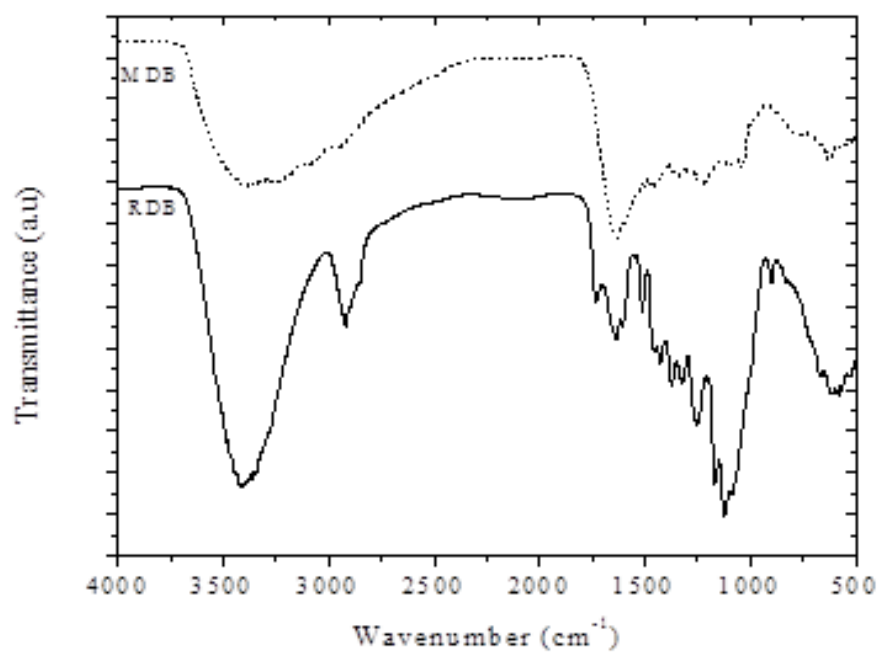

Figure 2: FTIR of (a) RDB and (b) MDB

The efficiency of metal ions removal by MDB was affected by the initial $\mathrm{pH}$ of the $\mathrm{Cd}$ (II) and $\mathrm{Cu}$ (II) metal ions solution. The adsorption of respective metal ions onto MDB showed that the removal efficiency increased with the increase in $\mathrm{pH}$ of the metal ions solutions till $\mathrm{pH}$ of around 5- 6. At low solution $\mathrm{pH}$, large quantity of protons $\left(\mathrm{H}^{+}\right)$existed which is greater as compared to metal ions and the competitions between $\mathrm{H}^{+}$with metal ions decreases their removal efficiency. Further metal ions removal above the optimal $\mathrm{pH}$ condition decreases owing to the excess hydroxyl ions at this region as well due to their precipitating nature. The result of the $\mathrm{pH}$ study showed that maximum removal efficiency obtained were at $\mathrm{pH}$ 6and 5 for $\mathrm{Cd}$ (II) and $\mathrm{Cu}$ (II), respectively as shown in fig. 3.

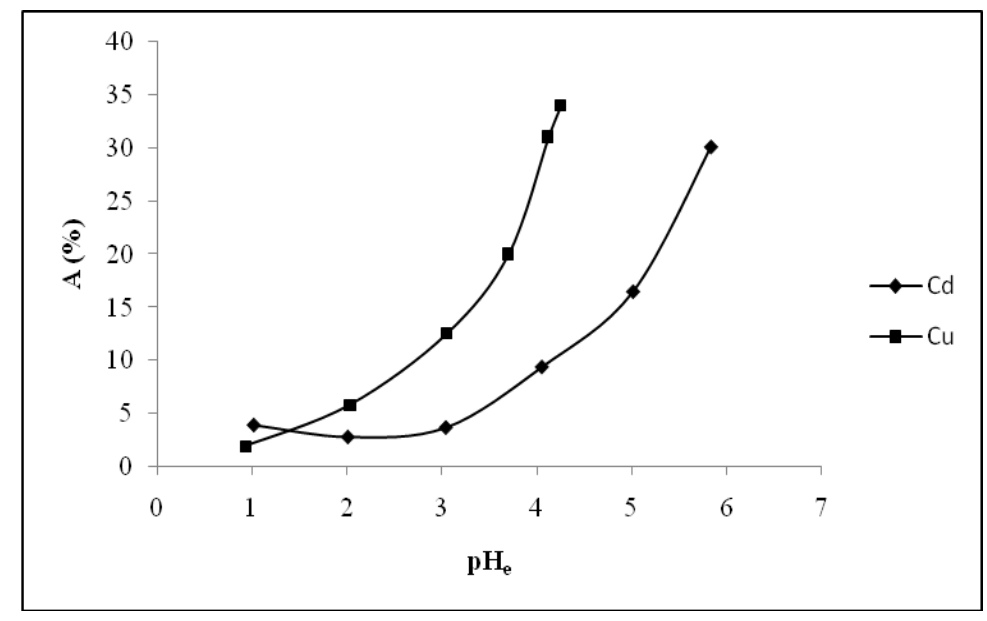

Figure 3: Effect of $\mathrm{pH}$ in the adsorption of $\mathrm{Cd}$ (II) and $\mathrm{Cu}$ (II) onto Modified Desmostachya bipinnata 
The effect of initial concentration of Cd (II) and Cu (II) ions removal were studied at 25 to $800 \mathrm{mg} / \mathrm{L}$ of metal ions at fixed adsorbent dose of $25 \mathrm{mg}$ at their optimum $\mathrm{pH}$ as shown in fig 4. The adsorption isotherms were evaluated with the help of linearzed Langmuir model represented by equation (3).

$$
\frac{C_{\mathrm{e}}}{\mathrm{q}_{\mathrm{e}}}=\frac{1}{\mathrm{q}_{\mathrm{m}} \mathrm{b}}+\frac{\mathrm{C}_{\mathrm{e}}}{\mathrm{q}_{\mathrm{m}}}
$$

Where $\mathrm{q}_{\mathrm{e}}(\mathrm{mg} / \mathrm{g})$ is the amount of adsorbed metal ions per $\mathrm{gm}$ of adsorbent, $\mathrm{C}_{\mathrm{e}}(\mathrm{mg} / \mathrm{L})$ is the residual concentration of metal ions after adsorption, $\mathrm{q}_{\mathrm{m}}(\mathrm{mg} / \mathrm{g})$ is the maximum adsorption capacity and $\mathrm{b}(\mathrm{L} / \mathrm{mg})$ is the binding constant. The Langmuir constant $\left(\mathrm{q}_{\mathrm{m}}\right.$ and $\left.\mathrm{b}\right)$ were calculated from plots of $\mathrm{C}_{\mathrm{e}} / \mathrm{q}_{\mathrm{e}}$ versus $\mathrm{C}_{\mathrm{e}}$. The Langmuir parameters are given in table 1.

Table1: Langmuir adsorption isotherm model parameters and experimental $q_{\max }$

\begin{tabular}{|c|c|c|c|c|}
\hline Metal ions & $\begin{array}{c}\text { Langmuir } \\
(\mathrm{mg} / \mathrm{g})\end{array}$ & $\begin{array}{l}\text { Experimental } \mathrm{q}_{\max } \\
(\mathrm{mg} / \mathrm{g})\end{array}$ & $\mathrm{b}(\mathrm{L} / \mathrm{mg})$ & $\mathrm{R}^{2}$ \\
\hline $\mathrm{Cd}$ (II) & 34.48 & 30.40 & 0.012 & 0.998 \\
\hline & & & & 0.995 \\
\hline $\mathrm{Cu}$ (II) & 45.45 & 41.60 & 0.014 & \\
\hline
\end{tabular}

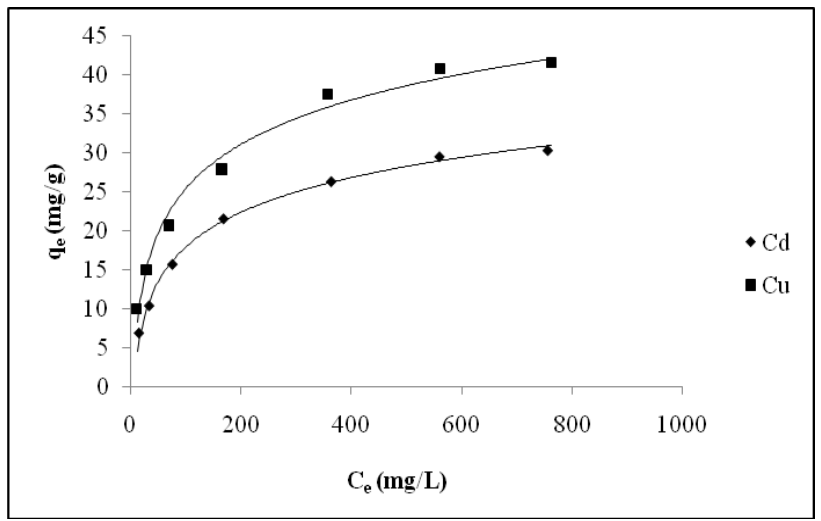

Figure 4: Adsorption isotherm for the Cd (II) and Cu (II) onto Modified Desmostachya bipinnata

Based on the correlation coefficient $\left(\mathrm{R}^{2}\right)$ value, the adsorption isotherms for the $\mathrm{Cd}$ (II) and $\mathrm{Cu}$ (II) were well described by the Langmuir equation. The maximum adsorption values $\left(\mathrm{q}_{\mathrm{m}}\right)$ were $30.4 \mathrm{mg} / \mathrm{g}$ and $41.6 \mathrm{mg} / \mathrm{g}$ for $\mathrm{Cd}$ (II) and $\mathrm{Cu}$ (II), respectively. On the other hand, theoretical monolayer capacity $\left(\mathrm{q}_{\mathrm{m}}\right)$ of the respective metal ions based on the Langmuir adsorption equation as shown in fig. 5, were determined to be $34.48 \mathrm{mg} / \mathrm{g}$ and $45.45 \mathrm{mg} / \mathrm{g}$, respectively, which are in close agreement with the experimental $\left(\mathrm{q}_{\mathrm{m}}\right)$ results suggesting that heavy metals can be quantitatively removed by the (MDB) biosorbent.

The effect of contact time on the removal of $\mathrm{Cd}$ (II) and $\mathrm{Cu}$ (II) metal ions from aqueous solution by biosorbent were studied using pseudo-second order kinetic models as shown in fig. 6 . The kinetic plots of $\mathrm{t} / \mathrm{q}_{\mathrm{t}}(\mathrm{min} / \mathrm{mg} / \mathrm{g})$ versus $\mathrm{t}(\mathrm{min})$ gave the straight line for the respective metal ions onto the MDB as shown in fig. 7, indicating that adsorption reaction can be approximated with pseudo-second order kinetic model given by Ho and McKay ${ }^{13}$. 




Figure 5: Langmuir plot for the adsorption of $C d$ (II) and $C u$ (II) onto Modified bipinnata

$$
\frac{t}{\mathrm{q}_{\mathrm{t}}}=\frac{1}{K_{2} q_{e}^{2}}+\frac{\mathrm{t}}{q_{e}}
$$

Where $\mathrm{q}_{\mathrm{t}}(\mathrm{mg} / \mathrm{g})$ is the amount of adsorption at time $\mathrm{t}(\mathrm{min}), \mathrm{K}_{2}(\mathrm{~g} / \mathrm{mg} / \mathrm{min})$ is the rate constant of the pseudo- second order kinetic adsorption. Value of $\mathrm{K}_{2}$ and $\mathrm{q}_{\mathrm{e}}$ can be obtained from the intercept and slope of the of experimental $t / q_{t}$ versus $t$, which is given in table 2 .

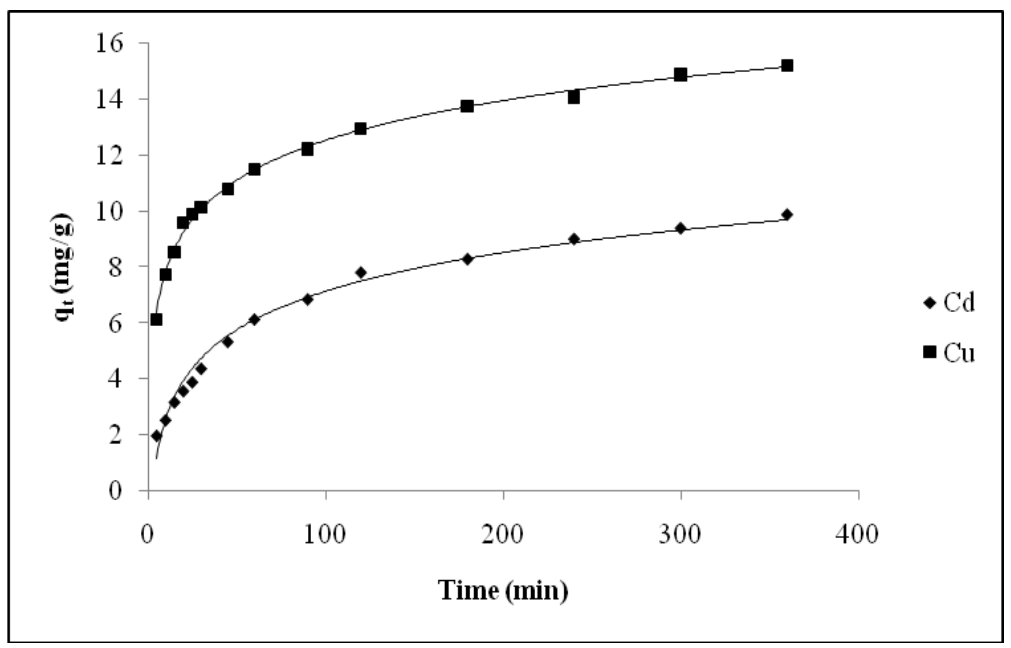

Figure 6: Adsorption kinetics of $\mathrm{Cd}(\mathrm{II})$ and $\mathrm{Cu}$ (II) onto Modified Desmostachya bipinnata 
Table2: Sorption kinetics of pseudo second order for Metal ions onto MDB

\begin{tabular}{|c|c|c|}
\hline Metal ions & $\mathrm{R}^{2}$ & $\mathrm{~K}_{2}(\mathrm{~g} / \mathrm{mg} / \mathrm{min})$ \\
\hline $\mathrm{Cd}$ (II) & 0.997 & $2.339 \times 10^{-3}$ \\
\hline & & \\
\hline $\mathrm{Cu}$ (II) & 0.995 & $3.824 \times 10^{-3}$ \\
\hline
\end{tabular}

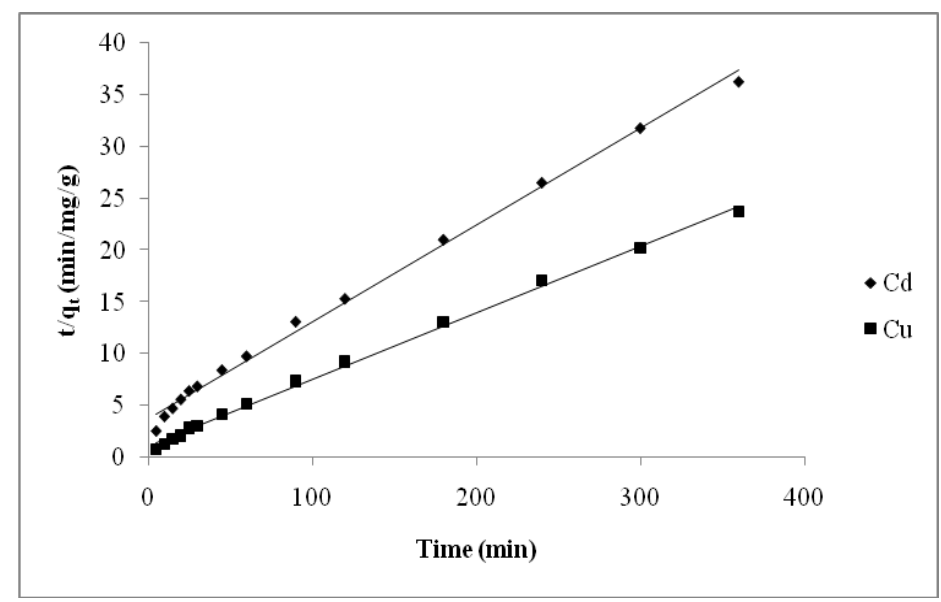

Figure 7: Pseudo second- order kinetic model in the adsorption of $\mathrm{Cd}$ (II) and $\mathrm{Cu}$ (II) onto Modified Desmostachya bipinnata

The result showed that the adsorption increased with the increase in time from 5 minutes to 100 minutes and then it became almost constant. So the best contact time was considered at 90 to 100 minutes. The correlation coefficient for the second order kinetic model is greater than 0.99 , which indicated that the adsorption model followed the pseudo second-order kinetic model.

\section{Conclusions}

This research work has introduced a new adsorbent Desmostachya bipinnata (DB) which is available at local level at almost free of cost. Elemental analysis, SEM and FTIR analysis revealed the introduction of amine group onto the DB. Equilibrium isotherms and kinetic studies performed by batch adsorption experiments at their optimum $\mathrm{pH}$ indicated that $\mathrm{DB}$ has reasonable maximum adsorption capacities for $\mathrm{Cd}$ (II) and $\mathrm{Cu}$ (II) metal ions, respectively. The adsorption process followed the pseudo second order kinetics. Based on the properties and maximum loading capacity for the tested metal ions, the chemically modified DB can be an ecofriendly and cost effective alternative for the removal of heavy metal ions from aqueous solution. However further studies concerning recovery of heavy metals experiment and reuse of biosorbent should be carried out to investigate the potential of MDB and improve the adsorption process. 


\section{Acknowledgements}

One of the authors J. Kour would like to thank Department of Agricultural Biotechnology, Padua University, Italy for providing the laboratory facilities; and the cultural and scientific agreement programme between Padua University and Tribhuvan University (Prof. Caravello, Padua University and Prof. Promod. K. Jha, TU.) for financing this research and University Grand Commission, Bhaktapur, Nepal for the Ph.D fellowship to carried out this research work.

\section{References}

1. S. Joshi, Study of toxicity of Pb (II) on fresh water pond snail Lymnea luteola, Graduate Degree thesis, University of Poona, India, 1987, pp.51.

2. K. Kadirvelu, K. Thamaraiselvi, C. Namasivayam, Bioresour. Technol., 2001a.76, 63-65.

3. B. Volesky, Removal and recovery of heavy metals by biosorption. In: Volesky B, editor. Biosorption of heavy metals. Boca Raton: CRC press, 1990, p. 12-31.

4. R. Ayyappan, A. Carmalin Sophia, K. Swaminathan, S. Sandhya, Process Biochemistry, 2005, 40, 1293-1299.

5. H. K. Alluri, S. R. Ronda, V. S. Settalluri, J. S .Bondili, Suryanarayana.V and Venkateshwar. African. J. of Biotech, 2007, 6 (25), pp. 29242931.

6. S.A. Ahmed, Carbohydrate Polymers, 2011, 83, 1470-1478.

7. K. N. Ghimire, K. Inoue, K. Ohto, T. Hayashida, Separation Science and Technology, 2007, 42:9, 2003-2018.

8. K. N. Ghimire, K. Inoue, K. Ohto, T. Hayashida, Bioresource Technology, 2008, 99, 32-37.

9. $\quad$ S. Deng, R. Bai and J. P. Chen. Langmuir 2003, 19, 5058-5064.

10. L. Jin, R. B, Bai, Langmuir 2002, 18, 9765-9770.

11. R. L. Shriner, C. K. F. Hermann, T. C. Morrill, D.Y. Curtin, R. C. Fuson, The Systematic Identification of Organic Compounds, Seventh Ed. Wiley, New York, 1998, p. 324.

12. R. M. Silverstein, G. C. Bassler, T. C. Morril, Spectrometric Identification of Organic Compounds, John Willey and Sons: New York, 1981, p. 95.

13. Y. S. Ho, G. McKay, Process Biochem., 1999, 34, 451. 